DOI: https://doi.org/10.34069/AI/2021.48.12.24

How to Cite:

Semenov, O., Semenova, N., Fenko, M., Zdikhovskyi, A., \& Udot, V. (2021). Empirical research of the development of the emotional and volitional spheres of older preschool children. Amazonia Investiga, 10(48), 228-237. https://doi.org/10.34069/AI/2021.48.12.24

\title{
Empirical research of the development of the emotional and volitional spheres of older preschool children
}

\section{Емпіричне дослідження розвитку емоційно-вольової сфери дітей старшого дошкільного віку}

Received: November 23, 2021

\section{Abstract}

The aim of the article is an empirical study of psychological determinants and significant correlations between the development of older preschool children's emotional and volitional spheres. The importance of preschool age in the development of the child's psyche, feelings, emotions, self-control, empathy, and reflexive capacities was emphasized. Self-control was found to be low in a significant proportion of the respondents $(n=46 ; 62.16 \%)$. The emotional reaction, which is the child's empathic ability to empathize and sympathize, had high levels, according to the study (M1= 18.12; M2=12.00; M3=10.01). The empathetic capacity of a senior preschooler was in the active development phase and encourages the formation of empathic and reflexive abilities through play activities, particularly through such a form of leading mental activity as story-role play. The correlation matrix revealed that "Self-control" and "Emotional response" had a positive and relevant correlation $(\mathrm{rs}=.141 ; \mathrm{p}<.05)$. It is stated that the
Accepted: December 30, 202

Written by:

Oleksandr Semenov ${ }^{100}$ https://orcid.org/0000-0002-3839-4725

Nataliia Semenova ${ }^{101}$ https://orcid.org/0000-0002-5247-7439

Mariia Fenko' ${ }^{102}$ https://orcid.org/0000-0003-2000-2348

Andrii Zdikhovskyi ${ }^{103}$ https://orcid.org/0000-0002-8614-9935

Viktoriia Udot ${ }^{104}$ https://orcid.org/0000-0002-7737-8517

\section{Анотація}

Метою статті $\epsilon$ емпіричне дослідження психологічних детермінант i значущих кореляційних зв'язків розвитку емоційновольової сфери дітей старшого дошкільного віку. Акцентовано, що дошкільний вік $\epsilon$ періодом динамічного розвитку психіки дитини, іiі почуттів, емоцій, самоконтролю, емпатичних та рефлексивних здатностей. Встановлено, що самоконтроль у значної частини респондентів ( $\mathrm{n}=46 ; 62.16 \%)$ знаходиться на низькому рівні. Констатовано, що емоційний відгук, який $\epsilon$ емпатичною здатністю дитини співпереживати та співчувати, має високі показники за рівнями $(\mathrm{M} 1=\quad 18.12 ; \quad \mathrm{M} 2=12.00 ; \quad \mathrm{M} 3=10.01)$. Обгрунтовано, що через ігрову діяльність, зокрема через такий вид провідної психічної діяльності, як сюжетно-рольова гра, емпатична здатність старшого дошкільника знаходиться у фазі активного розвитку i сприяє формуванню емпатичної та рефлексивної здатностей. За допомогою

\footnotetext{
${ }^{100}$ Doctor of Pedagogical Sciences, Full Professor of the Department of General Pedagogy and Preschool Education, Volyn National University named after Lesia Ukrainka, Lutsk, Ukraine.

${ }^{101}$ Candidate of Pedagogical Sciences, Associate Professor of the Department of Pedagogy, Volyn National University named after Lesia Ukrainka, Lutsk, Ukraine.

${ }^{102} \mathrm{Ph}$. D. in Philology, Assistant Professor of the Department of General Pedagogy and Preschool Education, Volyn National University named after Lesia Ukrainka, Lutsk, Ukraine.

${ }^{103}$ Assistant Lecturer of Department of General Pedagogy and Preschool Education, Volyn National University named after Lesia Ukrainka, Lutsk, Ukraine.

${ }^{104}$ Assistant of the Department of General Pedagogy and Preschool Education, Volyn National University named after Lesia Ukrainka, Lutsk, Ukraine.
} 


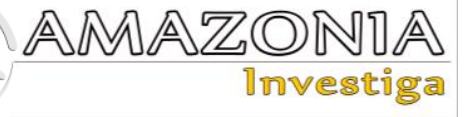

presence of this correlation in the researched groups was a good marker of older preschool children's emotional and volitional development.

Key words: empathy, emotions, volitional selfregulation, preschooler, story-role play.

кореляційної матриці встановлено позитивний значущий зв'язок між "Самоконтролем" та "Емоційним відгуком" $(\mathrm{rs}=.141 ; \mathrm{p}<.05)$. Пояснено, що наявність цього зв'язку у досліджуваних групах $\epsilon$ позитивним сигналом розвитку емоційновольової сфери дітей старшого дошкільного віку.

Ключові слова: емпатія, емоції, вольова саморегуляція, дошкільник, сюжетнорольова гра.

\section{Introduction}

The modern world places unique demands on individuals in order to improve their adaptation to the environment. The social environment is always changing, necessitating a person's activity, competition, resilience, and adaptability. In communication, activities, and interpersonal relationships, emotional intelligence and emotional regulation of a child's behavior are significant. The formation of an adequate level of ambitions and life aspirations is influenced by the development of the emotional and volitional spheres. It is known that emotions and feelings perform signaling and regulatory functions, motivating a person to knowledge, activities, and deeds or, conversely, stopping them from any actions and activities. In the present time, emotional and pedagogical study on emotional and volitional self-regulation is becoming increasingly significant. Special attention should be paid to solving key applied tasks of optimizing the functioning of regulatory processes in social interaction, improving efficiency in professional and educational activities, prevention of negative consequences of fatigue and research of psycho-emotional overload, and solving problems of spiritual safety of older preschool children.

Hypothesis. We assume that the empirical study of older preschool children's emotional and volitional development will reveal significant scientific facts that will be of practical relevance and should be operationalized in the preschool teaching and educational process.

The aim is to empirically establish psychological factors and significant correlations between the development of older preschool children's emotional and volitional spheres.

\section{Literature review}

When communicating with adults and peers, the child experiences a variety of emotions and feelings, demonstrates his or her attitude to what surrounds him or her, what is happening to him or her. These experiences form a sphere of emotions and feelings, which are a form of reflection of reality and the result of satisfaction or dissatisfaction with needs (Erikson, 1974).

Emotions are a direct experience of phenomena and situations for a child. They are the reactions of the child's body to a real or probable situation that promotes or does not contribute to life, which corresponds or does not correspond to their values and attitudes. At the same time, they represent a physiological deviation from homeostasis that manifests as powerful feelings and is associated with neuromuscular, respiratory, cardiovascular, hormonal, and other bodily changes. Emotions are a special class of subjective psychological states that manifest as direct experiences, feelings, and pleasant or unpleasant attitudes toward the world and other people, as well as in the processes and outcomes of a person's daily activities (Erina et al., 2020; Fisak et al., 2019; Halian et al., 2020a). Moods, feelings, emotions, passions, and stress are all aspects of a child's emotional state. All mental processes and states of a person are accompanied by emotions. The child's emotional and volitional spheres are extremely complex and sensitive.

Organic life, material order interests, and moral and spiritual needs are the three areas of emotional expressions of personality (Vygotsky, 1991). The child's affective and emotional sensitivity, subject feelings, and broader worldview feelings make up the organic sphere. Subject sentiments are associated with the ownership of specific subjects and activities. The marked emotions acquire depth and modality during the preschool age, in the game activity, particularly in story-role play. These feelings, according to objects, can be material, intellectual, or aesthetic. Some things or games may captivate 
the child, and he or she may refuse to part with them (girls with a favorite doll, boys with a car), or engage in activities with them while ignoring or avoiding other objects or games. Morals and attitudes toward the world, people, social events, moral categories, and values are all part of a child's worldview sentiments (Semenow, 2016a; Vilyunas, 1976). Emotions in children are complex bodily reaction that involves practically every portion of the neurological system. Emotions and feelings, like all other mental processes, are reflexive in nature. The activity of subcortical nerve centers is the physiological mechanism of emotions (hypothalamus, limbic system, reticular formation) (Semenov, 2017; Vilyunas, 1976). The emotional sphere of a child's personality is a multifaceted formation that includes many other emotional phenomena, in addition to emotions: emotional tone, emotional states (emotions), emotional personality traits, accentuated expressiveness of which allows us to talk about emotional personality types, emotionally stable relationships (feelings), and each of them has distinct, distinguishing features (Vilyunas, 1976). "Will" is a crucial component of a child's emotional and volitional spheres. Willpower is the ability to control one's personal behavior, activities, and communication in order to overcome internal and external difficulties. This is a human ability that manifests itself in selfdetermination and self-control of behavior and mental events. All voluntary actions have a specific goal in mind. However, in order for a child to attain their objectives, their actions must be coordinated. In the course of human social and historical evolution in working activity, a person's will was formed (Vygotsky, 1991).

The development of volitional regulation of a child's behavior takes place in multiple approaches. To begin with, it is the conversion of involuntary mental processes into arbitrary mental processes. Following that, the child gets control over their actions, which is followed by the development of individual volitional traits (Kovalenko, 2019; Semenov, 2017). This is a transition from the involuntary to the arbitrary nature of the activity. Language becomes a powerful tool for a child's mental and behavioral self-control (Pirozhenko \& Soroka, 2018). The expression of emotions in the newborn is a revival complex. At around 2-3 months of age, the baby responds to the mother's grin with a smile and general movement activation. In the second month of life, the initial elements of the revival complex arise. Early childhood is characterized by intense emotional reactions linked to the child's immediate desires (Semenow, 2016b; Vygotsky, 1991).

Preschool childhood is characterized by generally restless emotionality, the variability of strong emotional outbursts, and conflicts for minor reasons. The child's actions are based on ideas and direct expectations about the subject, the desired result, and the ability to achieve it in the near future. Emotions linked with overcoming obstacles can sometimes anticipate how a child's behaviors will turn out. Even before they begin to act, the preschooler has an emotional image that reflects both the future outcome and the adults' opinion of them (Popovych, 2014; Popovych et al., 2021a). Despite the fact that the child does not always know whether they will behave good or bad. If a child predicts a result that does not meet the accepted standards of education, the anxiety developed in the child - an emotional state that can inhibit undesirable actions for others (Fisak et al., 2019). Predicting the consequence of acts that are highly valued by others is obviously related to happy emotions, which stimulates the child's behavior even more. According to one study, preschool is the most important stage in a child's development. This is the moment of attachment to universal values and the beginning of the social relationship. Preschool age, on the other hand, is marked by a high level of vulnerability and sensitivity. At the current time, the main goal of modernizing preschool education is to promote the holistic development of the child as a person, which includes child health care (Semenova \& Semenov, 2014), as well as the integration of novel technologies into the teaching and educational process (Tsiuniak et al., 2020).

The child's individual motivational system begins to take shape during the preschool years. Motives become more consistent. Among them, the dominant motives stand out which are predominant in the form of a motivational hierarchy. As a result, strong-willed efforts to accomplish the goal arise (Erikson, 1974). For most children, the change from automatic to voluntary acts is accompanied by a lack of emotional fulfillment. It should be emphasized that the moral gratification of being able to undertake an act of will contributes to its effective completion.

Thus, the emotional and volitional spheres of older preschool children are an important component in child development, because no communication, interaction will have an effect if its participants do not seek to perceive, evaluate, 


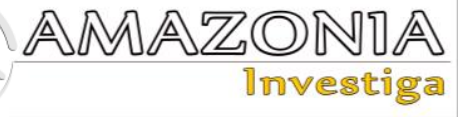

respond, control their emotional and volitional acts and act based on perception, analysis, and assessment of emotional and volitional acts of other participants in the interaction.

\section{Materials and methods}

The concepts of E. Erikson (1974), A. Kovalenko (2019), O. Semenov (2017), and L. Vygotsky (1991) served as the starting point and methodological foundation for the study of psychological determinants and the establishment of significant correlations between the development and formation of the emotional and volitional spheres of the older preschool child. The psychological content parameters of an older preschooler's emotional and volitional spheres were established using relevant psychodiagnostic methods. The proposed valid methods have been tested by researchers in the study of dominant psycho-emotional states in teaching and educational activities (Popovych et al., 2020a; 2020b), university education (Blynova et al., 2020c; 2020d), professional development and development of specialists (Blynova et al., 2020b; Halian et al., 2020b), in motivational (Popovych et al., 2020c) and adaptation processes (Blynova et al., 2020a; Khmiliar et al., 2020) and other areas of human activity (Shevchenko et al., 2020).

The proposed theoretical analysis and methodological principles contribute to the qualitative empirical investigation of psychological determinants and significant correlations between the development of older preschool children's emotional and volitional spheres.

Participants. The participants of the study are children of senior general $(n=3)$ and speech therapy $(n=1)$ groups of preschool education institutions: preschool education institution of Lutsk City Council № 5 "Piznayko" (Lutsk, Ukraine) - senior general and senior speech therapy groups, preschool education institution of Lutsk City Council № 10 "Volynyanochka" (Lutsk, Ukraine) - senior general group and preschool institution of Lutsk City Council № 17 "Kobzaryk" (Lutsk, Ukraine) - senior general group. The total number of older children at all stages of the study was $n=74$. Parents $(n=52)$, educators, and assistant educators $(n=12)$ were involved in supporting the diagnostic process. The mean age of older preschoolers was 5.4 years $(\mathrm{SD}=.78)$.

Instruments. Theoretical and empirical research methods were used. Theoretical methods were presented by retrospective analysis, systematization, generalization, and substantiation of scientific facts. Empirical methods were used: test-questionnaire "Study of voluntary self-regulation" ("SVSR") (Zverkova, \& Eidman, 2010; adapted by O. Semenov); questionnaire "Balanced Emotional Empathy Scale" ("BEES") (Mehrabian, 1997; adapted by O. Semenov); anxiety test "Choose a necessary person" (Temml et al., 1992); method "Magic Land of Senses" (Zinkevich-Evstigneeva \& Grabenko, 2006).

The test-questionnaire "Study of voluntary selfregulation" ("SVSR") (Zverkova, \& Eidman, 2010; adapted by O. Semenov) is designed to determine the volitional self-regulation of the individual. This method allows determining the level of development of voluntary self-regulation of respondents. The moment of documenting the results of self-knowledge, emotions, and value attitudes toward oneself is an important part of measuring the test. This inclusion is relevant at all stages of the behavioral act's implementation, from the motivating components through their own assessment of the behavior's achieved result. The test determined the "voluntary selfregulation" index on the points of the general scale (VSR), as well as the index on the subscales "perseverance" (P) and "self-control" (SC). The internal consistency of the empirical data is shown by the $\alpha$-Cronbach coefficient, which is at a level of .867, which is regarded as a high level $(h=.9)$ for this type of research.

The questionnaire "Balanced Emotional Empathy Scale" ("BEES") was used to evaluate respondents' empathy (Mehrabian, 1997; adapted by O. Semenov). Emotional empathy is defined as the ability to empathize with another person, to feel what he or she is feeling, to experience similar emotional states, and to identify with him or her. The adapted method allows evaluating the child's overall empathetic tendencies, taking into consideration factors such as the level of expression of the ability to respond emotionally to an experience and the degree of consistency or inconsistency with the indicators of the object and subject of empathy. In everyday life, the objects of empathy are social events and circumstances with which the child interacts and empathizes. The method allows showing different shades of emotion depending on the situation. The $\alpha$-Cronbach coefficient, which measures the internal consistency of empirical data, is at a level of .909 , which is regarded to be a high level $(h=.9)$ for this type of research. 
The anxiety test "Choose a necessary person" (Temml et al., 1992) is developed to evaluate an older preschool child's level of anxiety. The experimental material consists of fourteen pictures, each of which depicts a situation that a senior preschooler may encounter. Each drawing has two versions: one for a girl (a girl is drawn) and one for a boy (a boy is depicted). Only the contour of the child's head is painted, not the child's face. Each picture is complemented by two images of the child's head, which exactly matches the contours of the face in the picture. One picture depicts a happy face, while the other depicts a sorrowful face. The child is shown the photographs in a specific order, one after the other. The discussion is held in a separate room. The researcher delivers instructions to the child by showing them an image. The anxiety test is analyzed using both quantitative and qualitative methods. The level of anxiousness is determined during the analysis. This allows determining whether the child has negative or positive attitudes regarding various life experiences. Each picture represents a situation that is common in a child's life.

The fairy tale therapy program includes the "Magic Land of the Senses" method (ZinkevichEvstigneeva \& Grabenko, 2006). Luscher's eight-color test is combined with this method. The method is convenient since the form is designed in the style of a fairy tale, allowing researchers to involve children in the study process to a larger extent. The method's goal is to examine the child's psycho-emotional state. This method helps to visualize the child's psycho-emotional state graphically.

Procedures. Theoretical relevant problems were addressed at the beginning of the study, and methodological instruments for studying the individuals' emotional and volitional spheres were chosen. Empirical research has been validated, allowing us to gather scientific data regarding a child's emotional and volitional spheres when they are older than preschool age. After that, an empirical study was conducted, which involved children, teachers and parents of children. The total number of participants (children) was $n=74$. There were 39 boys and 35 girls among them, representing $52.70 \%$ and $47.30 \%$, correspondingly. The older preschool children were selected from four senior preschool groups, three of which were general and one of which was speech therapy. To compare some criteria of the development of the emotional and volitional spheres in the respondents, a speech therapy group (children with speech abnormalities who practice with a speech therapist under a particular program) was used. The comparison was made using the anxiety test "Choose a necessary person" (Temml et al., 1992). The research was agreed with the administration of preschool institutions and the Committee on Research Ethics. All ethical requirements for scientific research have been met. All participants in the study participated voluntarily and were informed about the progress of the study and that they could stop it at any time. The researchers obtained data that was processed and substantiated.

Statistical Analysis. The statistical analysis of the empirical results of a study was carried out using the computer program "MS Excel 2011" and the statistical software package "SPSS" v. 24.0. To evaluate the parameters of the development of the emotional and volitional spheres of older preschool children, reliable valid methods were used. The criteria $(\varphi)$ of Fisher's angular transformation was used to demonstrate statistically significant differences between the parameters of the anxiety test established in speech therapy and general groups. A correlation matrix was created and Spearman's test (rs) was used to establish correlations.

\section{Results and discussion}

Table 1 demonstrates the results of psychodiagnostic methods which are the testquestionnaire "Study of volitional selfregulation" ("SVSR") (Zverkova, \& Eidman, 2010; adapted by O. Semenov) and the questionnaire "Balanced Emotional Empathy Scale" ("BEES") (Mehrabian, 1997; adapted by O Semenov), that are adapted for older preschool children (Semenov, 2017). 
Table 1.

Frequency characteristics by methods "Study of volitional self-regulation" and "Balanced Emotional Empathy Scale”

\begin{tabular}{|c|c|c|c|c|c|c|c|c|c|}
\hline \multirow{3}{*}{ Scale } & \multicolumn{9}{|l|}{ Level } \\
\hline & \multicolumn{3}{|l|}{ High } & \multicolumn{3}{|c|}{ Middle } & \multicolumn{3}{|l|}{ Low } \\
\hline & M1 & $\mathbf{n}$ & $\%$ & M2 & $\mathbf{n}$ & $\%$ & M3 & $\mathbf{n}$ & $\%$ \\
\hline \multicolumn{10}{|l|}{ "SVSR" } \\
\hline Volitional self-regulation (VSR) & 15.32 & 16 & 21.62 & 12.02 & 30 & 40.54 & 8.15 & 28 & 37.84 \\
\hline Perseverance $(\mathrm{P})$ & 10.12 & 14 & 18.92 & 8.28 & 32 & 43.24 & 6.76 & 28 & 37.84 \\
\hline Self-control (SC) & 8.02 & 9 & 12.16 & 5.24 & 19 & 25.68 & 3.87 & 46 & 62.16 \\
\hline \multicolumn{10}{|l|}{ "BEES" } \\
\hline Emotional response (ER) & 18.12 & 28 & 37.84 & 12.00 & 26 & 35.14 & 10.01 & 20 & 27.02 \\
\hline
\end{tabular}

Note: $\mathrm{M}_{1}, \mathrm{M}_{2}, \mathrm{M}_{3}$ - arithmetic mean; $\mathrm{n}$ - number of respondents; \% - the number is presented as a percentage.

The results obtained by the method of "Study of volitional self-regulation" and the distribution of the levels (high, medium, and low) on the scales: "Volitional self-regulation $\quad\left(\mathrm{M}_{1}=15.32\right.$; $\left.\mathrm{M}_{2}=12.02 ; \quad \mathrm{M}_{3}=8.15\right)$, "Perseverance" $\left(\mathrm{M}_{1}=\right.$ 10.12; $\left.\mathrm{M}_{2}=8.28 ; \mathrm{M}_{3}=6.76\right)$ and "Self-control" $\left(\mathrm{M}_{1}=8.02 ; \mathrm{M}_{2}=5.24 ; \mathrm{M}_{3}=3.87\right)$, gave grounds to state that the psychological semantic parameters of voluntary self-regulation in older preschool children have a low level of development, as prevailing medium and low levels. As for selfcontrol, a significant part $(n=46 ; 62.16 \%)$ also had a low level. Another situation was with the emotional response, which is the child's empathic ability to empathize and sympathize. At each level, the emotional response had the following arithmetic mean values: $\mathrm{M}_{1}=18.12$; $\mathrm{M}_{2}=12.00 ; \mathrm{M}_{3}=10.01$. The obtained data confirmed that through play activities, in particular through the leading type of mental activity - story-role play - the empathic ability of a senior preschooler is in the phase of active development.

Table 2.

The results of the speech therapy group by parameters of the anxiety test "Choose a necessary person"

\begin{tabular}{lllll}
\hline Respondent & Anxiety index, \% & $\begin{array}{l}\text { Child-child anxiety } \\
\text { index, \% }\end{array}$ & $\begin{array}{l}\text { Child / adult anxiety } \\
\text { index, \% }\end{array}$ & $\begin{array}{l}\text { Anxiety index of } \\
\text { daily actions, \% }\end{array}$ \\
\hline 1AA & 53.33 & 40.00 & 60.00 & 60.00 \\
2AB & 33.33 & 60.00 & 20.00 & 20.00 \\
3AC & 53.33 & 60.00 & 60.00 & 40.00 \\
4BF & 60.00 & 80.00 & 40.00 & 60.00 \\
5BK & 33.33 & 60.00 & 40.00 & 0.00 \\
6DE & 80.00 & 80.00 & 100.00 & 60.00 \\
7DR & 80.00 & 60.00 & 60.00 & 40.00 \\
8DV & 53.33 & 60.00 & 20.00 & 20.00 \\
9ID & 60.00 & 60.00 & 80.00 & 40.00 \\
10IG & 20.00 & 40.00 & 0.00 & 20.00 \\
11IN & 46.73 & 40.00 & 80.00 & 20.00 \\
12IO & 26.73 & 40.00 & 40.00 & 0.00 \\
13IS & 53.33 & 60.00 & 60.00 & 40.00 \\
14MA & 40.00 & 60.00 & 60.00 & 0.00 \\
15MD & 33.33 & 60.00 & 20.00 & 20.00 \\
16MF & 60.00 & 100.00 & 40.00 & 40.00 \\
17MW & 46.73 & 40.00 & 60.00 & 40.00 \\
18NA & 33.33 & 40.00 & 40.00 & 20.00 \\
19NB & 53.33 & 60.00 & 60.00 & 100.00 \\
20NC & 73.33 & 80.00 & 40.00 & 0.00 \\
21ND & 33.33 & 40.00 & 60.00 & 40.00 \\
22PI & 66.37 & 60.00 & 40.00 & 100.00 \\
23QE & 33.33 & 40.00 & 60.00 & 0.00 \\
24RA & 53.33 & 60.00 & 60.00 & 40.00 \\
25ST & 46.37 & 60.00 & 60.00 & 20.00 \\
M & 49.00 & 57.60 & 50.40 & 33.60 \\
\hline NOE: M & & & &
\end{tabular}

Note: $\mathrm{M}$ - arithmetic mean. 
The anxiety index in children in the senior speech therapy group was medium $(M=49.00)$, according to the data analysis. We claim that older children's emotional and volitional spheres, in both speech therapy and general groups, were insecure and vulnerable to external influences. The emotional state of children was changeable, partly were changing rapidly from situation to situation. Emotions and feelings were difficult for children to control. The arithmetic mean of the data from the general groups differed significantly, $M=67.33$, as assessed by Fisher's criterion $\left(\varphi_{\mathrm{emp}}=1.78 ; \mathrm{p}<.05\right)$, although observations showed significant instability, situationality, and variability.

The obtained results indicated that in the speech therapy group it is necessary to pay attention to the methods of education, on the features of the emotional and volitional spheres of children. It is necessary to study the child's environment and offer a system of parenting methods that will reduce the level of anxiety and make stress exposure safe for the child's psyche, teach children to control their emotions according to the situation in which they find themselves.
Complementing the data obtained were the results of the method "Magic Land of Senses" (Zinkevich-Evstigneeva \& Grabenko, 2006). The obtained data showed that in children of older groups the psycho-emotional state had the following distribution by levels: high $-22.97 \%$ $(\mathrm{n}=17)$; medium $-45.95 \%(\mathrm{n}=34)$ and low $31.08 \%(\mathrm{n}=23)$. Children with a high level of psycho-emotional state used all the colors when painting the houses and adequately placed the colors on the "Country Map". Children with intermediate level used the color scheme quite accurately, but some of the colors remained unused. There was a dominance of favorite color. Children from the speech therapy group, respectively, had lower scores. Not all colors were used when painting the houses (there were repetitions), and the colors were placed inadequately on the "Country Map".

Table 3 demonstrates a correlation matrix of the establishment of correlations between the studied parameters of the methods "Study of volitional self-regulation" and "Balanced Emotional Empathy Scale".

Table 3.

Correlation matrix of parameters by parameters of methods "Study of volitional self-regulation" and "Balanced Emotional Empathy Scale"

\begin{tabular}{llllc}
\hline Scale & $\begin{array}{l}\text { Volitional self- } \\
\text { regulation (VSR) }\end{array}$ & $\begin{array}{l}\text { Perseverance } \\
(\mathbf{P})\end{array}$ & $\begin{array}{l}\text { Self-control } \\
(\text { SC) }\end{array}$ & $\begin{array}{l}\text { Emotional } \\
\text { response (ER) }\end{array}$ \\
\hline Volitional self-regulation & 1.000 & $.644^{* *}$ & $.356^{* *}$ & .076 \\
(VSR) & $.644^{* *}$ & 1.000 & $.249^{* *}$ & .031 \\
Perseverance (P) & $.356^{* *}$ & $.249 * *$ & 1.000 & $.141^{*}$ \\
Self-control (SC) & .076 & .031 & $.141^{*}$ & 1.000 \\
Emotional response (ER) & .076
\end{tabular}

Note: * the correlation's significant at the level of .05 (bilateral); ** correlation's significant at the level of .01 (bilateral).

The correlations between "Volitional SelfRegulation" and "Perseverance" $\left(\mathrm{r}_{\mathrm{s}}=.644 ; \mathrm{p}<.01\right) \quad$ and "Self-Control" $\left(r_{s}=.356 ; p<.01\right)$ were clearly significant. There was also a significant correlation between "Perseverance" and "Self-Control" $\left(\mathrm{r}_{\mathrm{s}}=.249 ; \mathrm{p}<.01\right)$. An interesting scientific fact was the only significant positive correlation between "Self-Control" and "Emotional Response" $\left(\mathrm{r}_{\mathrm{s}}=.141 ; \mathrm{p}<.05\right)$. Obviously, this correlation indicated the elements of the origin of self-regulatory empathic and reflexive patterns in older preschool children. The presence of this connection in the studied groups was a positive signal of the development of the emotional and volitional spheres of older preschool children.

At the same time, comparing the results of the study of the senior general and speech therapy groups, we can say that the emotional and volitional spheres of children were developed and they can overcome stressful situations. However, parents and educators need to help children develop the skills of understanding and controlling their emotions and feelings, as well as understanding the emotions of others, developing empathic ability, skills of self-control, and responsibility for their actions and deeds.

The empirical results of our study are confirmed in the works of other researchers: Baisheva et al., 20219; Burkalo, 2019; Fisak et al., 2019; Pirozhenko \& Soroka, 2018. We have concretized the psychological semantic parameters of the emotional and volitional spheres, for which the senior preschool age is a sensitive period of development of the child's creative potential, which is outlined in another 


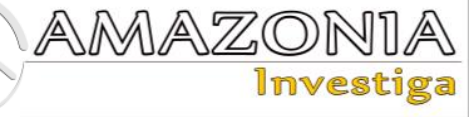

study (Semenov et al., 2021). In preschool-age, there is a formation of the basic personal mechanisms and new growths. Children have a close connection between the emotional and motivational spheres, self-awareness is formed (Kovalenko, 2019). The child's readiness for school is being formed, which marks the emergence of new conditions for the personal growth of the senior preschooler. During this period of time, the child's leading activity becomes learning and begins to develop a range of business qualities of the child (Semenov et al., 2021).

The empirical facts we have found out may be used in the programs of development of the emotional and volitional spheres of senior preschoolers. These programs may be part of a set of activities focused on core human values, which is confirmed in modern research on values (Popovych et al., 2021b). These classes may help solve the problems of emotional and moral development of preschoolers. The outlined considerations will provide a perspective for our further scientific research.

\section{Conclusions}

The following conclusions are presented based on theoretical analysis and empirical research.

1. A preschool child's emotional and volitional spheres are an important component of the child's entire formation and development, as it contributes to the self-creation of the child's personality and determines their life path. Emotions serve as a kind of compass for understanding yourself and others. As a result, preschool age is an important period in the development of a child's personality, as the child's mind, feelings, emotions, selfcontrol, empathy, and reflexive capacities develop dynamically.

2. The proposed psychodiagnostic methods were related to the research subject and allowed the establishment of significant scientific facts.

3. The results of the scales "Volitional selfregulation" $\quad\left(\mathrm{M}_{1}=15.32 ; \quad \mathrm{M}_{2}=12.02\right.$; $\left.\mathrm{M}_{3}=8.15\right)$, "Perseverance" $(\mathrm{M} 1=10.12$; $\mathrm{M} 2=8.28 ; \quad \mathrm{M} 3=6.76)$ and "Self-control" $\left(\mathrm{M}_{1}=8.02 ; \mathrm{M}_{2}=5.24 ; \mathrm{M}_{3}=3.87\right)$ revealed that voluntary self-regulation in older preschool children is at a low level of development. A considerable fraction of the population $(\mathrm{n}=$ $46 ; 62.16 \%$ ) has low self-control.

4. It was indicated that the emotional response $\left(\mathrm{M}_{1}=18.12 ; \mathrm{M}_{2}=12.00 ; \mathrm{M}_{3}=10.01\right)$, which is the child's empathic ability to empathize and

sympathize, had high levels. This is explained by the fact that a senior preschooler's empathic ability is in the active development period due to storyrole play as a leading type of mental activity. Story-role play encourages the development of empathy and reflexivity.

5. A correlation matrix was created, and a significant positive correlation was established between "Self-Control" and "Emotional Response" $\left(r_{s}=.141 ; p<.05\right)$. The origin and formation of self-regulatory empathetic and reflexive tendencies in older preschool children explained this. We assumed that the presence of this correlation in the studied groups was a positive signal of the development of the emotional and volitional spheres of older preschool children.

6. The study's hypothesis was validated because the empirical facts of the study of the development of older preschool children's emotional and volitional spheres were substantial, have practical worth, and may be operationalized in the preschool teaching and educational process.

\section{Acknowledgments}

The empirical study was performed according to the state budget research topic "Theory and methods of personality formation in early and preschool age" (state registration number 0120U104752, Ministry of Education and Science of Ukraine) on the Department of General Pedagogy and Preschool Education of Volyn National University named after Lesia Ukrainka.

\section{Bibliographic references}

Baisheva, M., Maximova, L., Koryakina, T., Okoneshnikova, A., \& Leontieva, A. (2019). Spiritual safety of a personality as a pedagogical problem. Amazonia Investiga, 8(24), 121-129. Retrieved from: https://amazoniainvestiga.info/index.php/am azonia/article/view/957

Blynova, O., Chervinska, I., et al. (2020a). Social and Psychological Manifestations of Professional Identity Crisis of Labor Migrants. Revista Inclusiones, 7(3), 93-105. http://www.revistainclusiones.org/index.php /inclu/article/view/1318

Blynova, O., Kisil, Z., et al. (2020b). Psychological manifestations of professional marginality of future social welfare professionals. Revista Inclusiones, 7(SI), 218-233. 
http://www.revistainclusiones.org/index.php /inclu/article/view/1229

Blynova, O., Lappo, V., et al. (2020c). Corporate Culture of a Higher Education Institution as a Factor in Forming Students' Professional Identity. Revista Inclusiones, 7(SI), 481-496. http://www.revistainclusiones.org/index.php /inclu/article/view/1305

Blynova, O., Moiseienko, V., et al. (2020d). Assertiveness as a Factor of Students' Choice of Behavior Strategies in Social Interaction. Revista Inclusiones, 7(4), 259-272. http://www.revistainclusiones.org/index.php /inclu/article/view/1551

Burkalo, N. (2019). Psychological features of emotional intelligence. Psychological Journal, 5(7), 34-49. https://doi.org/10.31108/1.2019.5.7.3

Erikson, E. H. (1974). Dimensions of a New Identity. Jefferson Lectures in the Humanities. New York: W. W. Norton \& Company.

https://cyditiqawyz.vassilyk.com/eriksondimensions-of-a-new-identity-book43161pg.php

Erina, I. A., Mutaliyeva, A., Mikhalkova, O., \& Brevnova, S. (2020). Psychological Correction of Aggressive Behavior of Older Preschool Children in Fairy-Tale Therapy Discourse. Amazonia Investiga, 9(29), 297-306. https://doi.org/10.34069/AI/2020.29.05.34

Fisak, B., Persad, L., Gallegos, J., \& Barrett, P. (2019). Prevention of anxiety in preschoolaged children. In B. Fisak \& P. Barrett (Eds.), Anxiety in preschool children: Assessment, treatment, and prevention (pp. 215-237). Routledge/Taylor \& Francis Group. https://doi.org/10.4324/9781315213828-10

Halian, A., Halian, I., et al. (2020a). Emotional Intelligence in the Structure of Adaptation Process of Future Healthcare Professionals. Revista Inclusiones, 7(3), 447-460. http://www.revistainclusiones.org/index.php /inclu/article/view/1347

Halian, I., Machynska, N., et al., (2020b). Tolerance of uncertainty as a component of the process of life-creation of future educators. Revista Inclusiones, 7(SI), 512-528.

http://www.revistainclusiones.org/index.php /inclu/article/view/1307

Khmiliar, O., Popovych, I., et al., (2020). Spatial Regulation of Personality Behavior in the Conditions of Progression of the COVID-19 Pandemic. Revista Inclusiones, 7(SI), 289-306. http://www.revistainclusiones.org/index.php /inclu/article/view/1760
Kovalenko, A. (2019). Interpersonal Relations of Older Preschool-Age Children who are in the Institutional Care. Social Welfare Interdisciplinary Approach, 1(10), 47-56. http://dx.doi.org/10.21277/sw.v1i9.465

Mehrabian, A. (1997). Analysis of affiliationrelated traits in terms of the PAD Temperament Model. Journal of Psychology, 131, 101-117. https://doi.org/10.1080/00223989709603508

Pirozhenko, T., \& Soroka, I. (2018). Tendency and Dynamics of Communicative-Speech Development of a Preschool Age Child. Psycholinguistics, 24(1), 289-303. https://doi.org/10.31470/2309-1797-201824-1-289-303

Popovych, I., Arbeláez-Campillo, D. F., et al. (2021a). Time perspective in the professional activity of specialists of economic sphere. Cuestiones Políticas, 39(69), 424-445. https://doi.org/10.46398/cuestpol.3969.27

Popovych, I., Laliuk, G., et al., (2020a). Sociocultural metrics of the personal paradigm of orphans' upbringing in pedagogical theory and practice of Ukraine. Revista Inclusiones, 7(3), 343-356. http://www.revistainclusiones.org/index.php /inclu/article/view/1638

Popovych, I., Lymarenko, L., et al. (2020b). Research on the Effectiveness of Training Technologies' Implementation in Student Theater". Revista Inclusiones, 7(2), 104-121. http://www.revistainclusiones.org/index.php /inclu/article/view/261

Popovych, I., Shevchenko, A., et al. (2021b). Research of the relationship between social desirability and value orientations of adolescents. Revista Notas Históricas y Geográficas, 26(1), 241-268. https://www.revistanotashistoricasygeografi cas.cl/index.php/nhyg/article/view/339

Popovych, I. S. (2014). Social expectations in primary school age. Proceedings of the 2 nd International Academic Congress "Fundamental Studies in America, Europe, Asia and Africa", 2, 176-180. http://ekhsuir.kspu.edu/handle/123456789/3 306

Popovych, I., Zhigarenko, I., et al. (2020c). Research of Achievement Motivation's Impaction the Career Orientations of Future Managers of Organization. Revista Inclusiones, 7(SI), 247-263. http://www.revistainclusiones.org/index.php /inclu/article/view/1231

Shevchenko, R., Cherniavskyi, V., et al., (2020). Research of psychophysiological features of response to stress situations by future sailors. Revista Inclusiones, 7(SI), 566-579. 


\section{AMAZOND周 \\ 1ึvestiำ}

http://www.revistainclusiones.org/index.php /inclu/article/view/1780

Semenova, N., \& Semenov, O. (2014). Formation of Responsible Attitude to Health of Pre-School Children in Mountainous Terrain. Journal of Vasyl Stefanyk Precarpathian National University, 1, 229-234. https://doi.org/10.15330/jpnu.1.23.229-234

Semenov, O., Semenova, N., Bielienka, H., Alendar, N., Yemchyk, O., \& Onyschuk, I. (2021). Empirical Research of a Creatively Oriented Personality's Formation of a Child of Senior Preschool Age. Romanian for Multidimensional Education [Revista Romaneasca Pentru Educatie Multidimensionala], 13(4), 413-434. https://doi.org/10.18662/rrem/13.4/490

Semenov, O. S. (2017). Theoretical and Methodological Principles of Formation of Creative Personality of Senior Preschooler in Out-of-School Educational Institution. (Extended abstract of Doctor's thesis). Kyiv: Institute of Problems on Education of NAES of Ukraine. https://lib.iitta.gov.ua/709175/1/Semenov_ar ef.pdf

Semenow, O. (2016a). Analysis of the pedagogue's professional qualities that determine the creative development of the pupil. Tradition - the present - the future of preschool and early childhood education, 1, 243-247.

http://dlibra.bg.ajd.czest.pl:8080/Content/44 71/21.pdf

Semenow, O. (2016b). The role of the pedagogue in the creative development of the pupil. Education, $\quad \mathrm{XXV}(2)$, 53-60. http://dx.doi.org/10.16926/p.2016.25.56

Temml, R., Dorki, M., \& Umen, V. (1992). Anxiety test "Choose a necessary person". Studmi. [Electronic resource]. Retrieved from:

https://studme.org/325269/psihologiya/test_t revozhnosti_temml_dorki_amen

Tsiuniak, O., Pyslar, A., et al., (2020). Research of interdependence of variables and factor structure of masters' readiness for innovative pedagogical activity. Revista Inclusiones, $7(3)$, 427-452. http://www.revistainclusiones.org/index.php /inclu/article/view/1645

Vilyunas, V. K. (1976). Psychology of emotional phenomena Moscow: MSU. http://childpsy.ru/lib/books/id/8094.php

Vygotsky, L. (1991). Imagination and creativity in childhood. Moscow: Prosveshcheniye. http://childpsy.ru/lib/books/id/8102.php

Zinkevich-Evstigneeva, T. D., \& Grabenko, T. M. (2006). Fairytale therapy games. St. Petersburg: Rech. https://gigabaza.ru/doc/186278.html

Zverkova, A. V., \& Eidman, E. V. (2010). Test questionnaire "Research of volitional selfregulation". - [Electronic resource]. Retrieved from: http://psylist.net/praktikum/00417.htm 